\title{
ANALYZING THE ROLE OF SOCIAL MEDIA IN INVESTMENT DECISION WITH SPECIAL REFERENCE TO SOUTH GUJARAT
}

\author{
Ekta Ashokkumar Mistri, Dr. Gurudutta P. Japee \\ Research Scholar, \\ S.D. School of Commerce, \\ Gujarat University, Ahmedabad. \\ Associate Professor, \\ S.D. School of Commerce, \\ Gujarat University, Ahmedabad.
}

\begin{abstract}
The purpose of this study is to analyze the role of social media in investment decisions which means changes in investment pattern after the enhancement of role of social media to a greater extent. This study primarily focuses on the South zone of Gujarat which include five districts: Surat, Bharuch, Navsari, Vapi and Valsad. South Gujarat has all the necessary natural resources, labor and government backing which are self sufficient for investors to invest. This particular area have world-class infrastructure and small scale industries, especially the textile industry which has really made South Gujarat as one of the most preferred destinations for investing. The hypothesis are tested through the questionnaires distributed to small investors who are using social media for investment purpose. The collected data are analyzed by using Statistical Package for the Social Sciences (SPSS) Software Version 20. By analyzing the participation of small individual investors investing through social media platform, researcher aims to examine their adaptability and attitude towards investment through social media platform. This study will be helpful for investors who keep themselves updated with social media platforms regarding investment purpose. This study will also be helpful to create awareness among financial advisors to attract their clients.
\end{abstract}

Keyword: Social media, Investment decision, Awareness, Attitude

\section{INTRODUCTION}

In the world of financial investment, timing is everything. In the past, successful decision-making was based on knowledge garnered from traditional media, trade publications, and personal connections. However, with the rise of social media, there is now a quicker, more efficient way of gathering data to influence investor's perception. And that's precisely where social media comes in. It is now widely accepted that Twitter has become the most immediate and up-to-date source of news on the planet. Stories often break on the platform hours before major news corporations have mentioned them, which is something shrewd investors have started to monetize.

As a result, five million affluent investors (those with investible assets of over $\$ 100,000$ ) in the US and Canada are now using social media to research financial decisions.

Keeping abreast of breaking news and industry developments via Twitter is of vital importance to serious investors. If they can purchase or offload stocks before the rest of the market becomes aware of a significant change, they put themselves at a considerable advantage when As well as using Twitter to react immediately to fresh news stories, investors can also use the platform to predict future market movements based on growing interest or sentiment in a particular area. LinkedIn is fantastic at building relevant networks of people and businesses. As with Twitter, it is simple for investors to connect to experts in any industry to obtain further insight into their market, with the added LinkedIn benefit that the content is exclusively professional.

Zak Mir, editor at trading publication Spreadbet Magazine, says that if you connect with or follow "the right twenty to thirty people in the trading and financial markets area, then you should be fully informed in terms of what to think, what to trade, and when to trade it."

LinkedIn is also a great place to carry out due diligence on investments, with investors able to assess both individuals and industries. As well as researching the relevant business leaders and industry influencers, investors can also look into active groups and judge whether, as with the Hunger Games, interest in a particular niche is growing. Just like Twitter sentiment, Facebook popularity can be a great way for investors to use social 


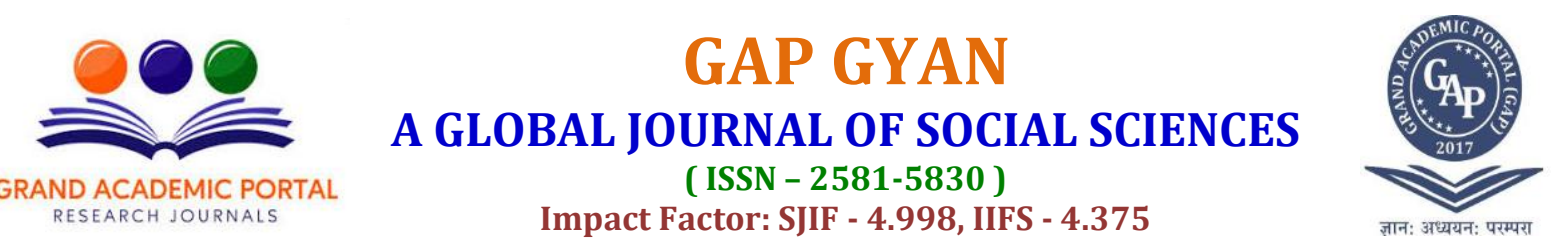

media to gauge potential stock market movements. It's clear that Twitter, LinkedIn, and Facebook have become extremely important in the investment world.

\section{STATEMENT OF THE PROBLEM}

This study focuses on small individual investors who invests limited amount of money in his/her account in one or more investment avenues. The small individual investors generally consider their investment needs, goals, objectives and constraints while making investment decision. Social media sites have become the most visited sites for the last few years. It has become the most popular platform to share personal \& professionals likes \& dislikes, views \& news, photographs \& videos and the most important medium of communication. All customers are using various applications like Whatsapp, Facebook and Twitter for their communication. Most financial companies providing various services have only piecemeal social presence. Social media is joining traditional financial news media as a key source of information used by institutional investors in their investment processes. Investors use social media as part of their regular work flow, especially in South Gujarat. Therefore this study is focused on finding out the effect of social media on their investment decision.

\section{REVIEW OF LITERATURE}

J. power and Phillips-Wren(2011) studied about 'Impact of Social Media and Web 2.0 on Decision Making.' This study suggests that the impact of social media on individual and organizational decision making can be extensive. The author posit that social networks, blogs and micro blogs are currently having the largest impact on decision making and offer their initial hypotheses based on literature and limited empirical evidence. This study concluded that the impact of social media on decision making should increase in the future and web 2.0 and similar technologies are likely to increase the rationality and effectiveness of decision making in some cases while negatively impacting decision making in other cases.

Bashir et al.(2013) identifying the factors that influence the Pakistan's individual investor behavior. The researcher took thirty four items under the five categories of variables were taken as independent: self image/firm image, neutral information, accounting information ,personal financial needs and advocate recommendation. A structured questionnaire was used and sample size of 125 was considered. For the purpose of data analysis mean, standard deviation and frequency distribution table of variance were used. The study showed that dividend paid, reputation of firm, feelings for a firm's products and services, get rich quick, firm's involvement in solving community problems, and firm's status in industry related to firm's image/self-image and accounting information are most influencing factor that influence the investment behavior and the 6 least influencing factors were Friend or coworker recommendations, Opinions of the firm's majority stockholder, recent price movement in the firm's stock, Religious Reason, Family member opinion and Broker recommendation.

Paniagua and Sapena (2014) conceptualized four channels by which social media impacts financial, Operational and corporate social performance such as social capital, customers' revealed preferences, social marketing and social corporate networking. The author explain that social media has significant impact on stock prices and firm's share value of publicly related companies but after a critical mass of followers is attained. Twitter has become an extremely popular service that generate value for business due to specific characteristics of micro-blogging. They also performed sensitivity analysis and chose nine random company from the NASDAQ index because firms on the NASDAQ are much more exposed to social media than firms on the Spanish IBEX and prove that Twitter is more powerful tool to enhance business performance than Facebook.

Palanissamy (2014) studied about the use of social media as a communication tool that is emerging and enhancing investor relations globally and specific exploration in Oman. The researcher realized that social media has created a new challenges for regulatory bodies to establish comprehensive set of rules and guidelines. This study showed that investors are asking to communicate more with directors instead of the usual management teams of various companies. The researcher concluded that some companies are using social media very effectively from a business-to-consumer perspective and social media are starting to affect the investor relations efforts of public companies as well.

Jin et al. (2017) studied about how startup social media activity influences funding outcomes. Main objective of this study was to investigate whether the use of social media is associated with increased success in raising venture capital financing. Study focus on social media activities on Twitter and venture finance data from Crunch Base and also found that strong Twitter influence(followers, mentions, impressions, sentiment) and an active social media presence increase the likelihood a start up will close the round, the amount raised and the breadth of the investor pool. The study concluded that startup firms active on social media have higher chances of getting funded, receive larger amounts of funding, and have a larger number of investors. It can be drawn from the result that social media improves an investor's ability to discover potential investment. 


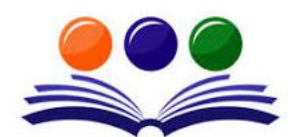

GRAND ACADEMIC PORTAL RESEARCH JOURNALS
A GLOBAL JOURNAL OF SOCIAL SCIENCES

( ISSN - 2581-5830 )

Impact Factor: SJIF - 4.998, IIFS - 4.375

\section{OBJECTIVES OF THE STUDY}

$>$ To know the relationship between age of respondents and their investment experience

$>$ To know the relationship between age of respondents and their frequency of using social networking apps

\section{RESEARCH METHODOLOGY}

\section{TYPE OF RESEARCH DESIGN}

This study focuses on descriptive research design.

\section{TYPE OF SURVEY}

The research has used sample survey.

\section{TYPE OF UNIVERSE}

The first step in developing any sample design is to clearly define the set of objects, technically called the universe of the studies. There are two types of universe finite or infinite universe. The present research is based on the finite universe and the number of item is finite.

\section{POPULATION}

The present study focus on south zone of Gujarat.The zone includes five districts Surat, Navsari , Bharuch, Vapi and Valsad.

\section{DATA COLLECTION}

There are two types of data collection method: Primary and Secondary data collection method. For this study, we have used primary data collection method. In this study primary data of 308 respondents have been collected through structure questionnaire prepared in goggle form the different districts of South Gujarat as per Random Sampling method. Researcher has tried to avoid ambiguity from the questionnaire.

\section{RESEARCH TOOLS}

The data collected from the respondents has been categorized, tabularized and analyzed by using applicable statistical and mathematical techniques. Frequency tables, charts and statistical results has been derived by using Microsoft Excel tool and statistical computer software called SPSS and for the analysis of data Chi-Square test was used.

\section{MAJOR FINDINGS}

\section{Hypothesis}

1) $\mathrm{H} 0$ : There is no significant relation between age of respondents and investment experience of respondents H1: There is a significant relation between age of respondents and investment experience of respondents

Table - 1: Cross tabulation of age of respondents and investment experience of respondents

\begin{tabular}{|c|c|c|c|c|c|c|c|c|}
\hline \multicolumn{9}{|c|}{ Cross tabulation } \\
\hline & & & \multicolumn{5}{|c|}{ Investment experience of respondents } & \multirow{2}{*}{ Total } \\
\hline & & & $0<2$ & $2-5$ & $6-10$ & $11-15$ & $>15$ & \\
\hline \multirow{10}{*}{$\begin{array}{c}\text { Age of } \\
\text { respondents }\end{array}$} & \multirow[b]{2}{*}{$18-30$} & Count & 74 & 46 & 10 & 2 & 0 & 132 \\
\hline & & $\begin{array}{l}\% \text { within Age of } \\
\text { respondents }\end{array}$ & $56.1 \%$ & $34.8 \%$ & $7.6 \%$ & $1.5 \%$ & $0.0 \%$ & $100.0 \%$ \\
\hline & \multirow[b]{2}{*}{$31-40$} & Count & 19 & 37 & 17 & 1 & 1 & 75 \\
\hline & & $\begin{array}{l}\% \text { within Age of } \\
\text { respondents }\end{array}$ & $25.3 \%$ & $49.3 \%$ & $22.7 \%$ & $1.3 \%$ & $1.3 \%$ & $100.0 \%$ \\
\hline & \multirow[b]{2}{*}{$41-50$} & Count & 23 & 11 & 16 & 22 & 7 & 79 \\
\hline & & $\begin{array}{l}\% \text { within Age of } \\
\text { respondents }\end{array}$ & $29.1 \%$ & $13.9 \%$ & $20.3 \%$ & $27.8 \%$ & $8.9 \%$ & $100.0 \%$ \\
\hline & \multirow[b]{2}{*}{$51-60$} & Count & 4 & 2 & 5 & 10 & 0 & 21 \\
\hline & & $\begin{array}{l}\% \text { within Age of } \\
\text { respondents }\end{array}$ & $19.0 \%$ & $9.5 \%$ & $23.8 \%$ & $47.6 \%$ & $0.0 \%$ & $100.0 \%$ \\
\hline & \multirow[b]{2}{*}{$\begin{array}{l}61 \text { and } \\
\text { above }\end{array}$} & Count & 0 & 0 & 0 & 0 & 1 & 1 \\
\hline & & $\begin{array}{l}\% \text { within Age of } \\
\text { respondents }\end{array}$ & $0.0 \%$ & $0.0 \%$ & $0.0 \%$ & $0.0 \%$ & $100.0 \%$ & $100.0 \%$ \\
\hline \multirow{2}{*}{\multicolumn{2}{|c|}{ Total }} & Count & 120 & 96 & 48 & 35 & 9 & 308 \\
\hline & & $\begin{array}{l}\text { \% within Age of } \\
\text { respondents }\end{array}$ & $39.0 \%$ & $31.2 \%$ & $15.6 \%$ & $11.4 \%$ & $2.9 \%$ & $100.0 \%$ \\
\hline
\end{tabular}




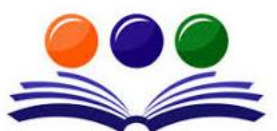

GRAND ACADEMIC PORTAL RESEARCH JOURNALS

A GLOBAL JOURNAL OF SOCIAL SCIENCES

( ISSN - 2581-5830 )

Impact Factor: SJIF - 4.998, IIFS - 4.375

Table 2: Chi-square test

\begin{tabular}{|c|c|c|c|}
\hline \multicolumn{4}{|c|}{ Chi-Square Tests } \\
\hline & Value & $\mathrm{df}$ & Asymp. Sig. (2-sided) \\
\hline Pearson Chi-Square & $155.619^{\mathrm{a}}$ & 16 & .000 \\
\hline Likelihood Ratio & 127.857 & 16 & .000 \\
\hline Linear-by-Linear Association & 75.160 & 1 & .000 \\
\hline N of Valid Cases & 308 & & \\
\hline a. 11 cells (44.0\%) have expected count less than 5. The minimum expected count is .03. \\
\hline
\end{tabular}

Sources: computed data \# Ho accepted at 5\%

From the above Pearson Chi- Square statistic table it can be seen that X2 $=155.619$, and $\mathrm{p}<0.05$, such data revealed that null hypothesis is rejected. So it is concluded that there exists a significant relationship between age of respondents and investment experience.

2) H0 : There is no significant relation between age of respondents and frequency of using social media $\mathrm{H} 1$ : There is significant relation between Age of respondents and Frequency of using social media

Table - 3: Cross tabulation of age of respondents and frequency of using social networking applications

\begin{tabular}{|c|c|c|c|c|c|c|c|}
\hline \multicolumn{8}{|c|}{ Crosstab } \\
\hline & & & \multicolumn{4}{|c|}{ Frequency of using social media } & \multirow[b]{2}{*}{ Total } \\
\hline & & & Everyday & $\begin{array}{l}\text { Once a } \\
\text { week }\end{array}$ & $\begin{array}{l}\text { Once a } \\
\text { month }\end{array}$ & Occasionally & \\
\hline \multirow{10}{*}{$\begin{array}{c}\text { Age of } \\
\text { respondents }\end{array}$} & \multirow[b]{2}{*}{$18-30$} & Count & 86 & 33 & 6 & 7 & 132 \\
\hline & & $\begin{array}{l}\% \text { within Age of } \\
\text { respondents }\end{array}$ & $65.2 \%$ & $25.0 \%$ & $4.5 \%$ & $5.3 \%$ & $100.0 \%$ \\
\hline & \multirow[b]{2}{*}{$31-40$} & Count & 47 & 12 & 3 & 13 & 75 \\
\hline & & $\begin{array}{c}\% \text { within Age of } \\
\text { respondents }\end{array}$ & $62.7 \%$ & $16.0 \%$ & $4.0 \%$ & $17.3 \%$ & $100.0 \%$ \\
\hline & \multirow[b]{2}{*}{$41-50$} & Count & 62 & 7 & 0 & 10 & 79 \\
\hline & & $\begin{array}{c}\% \text { within Age of } \\
\text { respondents }\end{array}$ & $78.5 \%$ & $8.9 \%$ & $0.0 \%$ & $12.7 \%$ & $100.0 \%$ \\
\hline & \multirow[b]{2}{*}{$51-60$} & Count & 16 & 3 & 0 & 2 & 21 \\
\hline & & $\begin{array}{c}\% \text { within Age of } \\
\text { respondents }\end{array}$ & $76.2 \%$ & $14.3 \%$ & $0.0 \%$ & $9.5 \%$ & $100.0 \%$ \\
\hline & \multirow[b]{2}{*}{$\begin{array}{l}61 \text { and } \\
\text { above }\end{array}$} & Count & 0 & 1 & 0 & 0 & 1 \\
\hline & & $\begin{array}{l}\% \text { within Age of } \\
\text { respondents }\end{array}$ & $0.0 \%$ & $100.0 \%$ & $0.0 \%$ & $0.0 \%$ & $100.0 \%$ \\
\hline \multirow{2}{*}{\multicolumn{2}{|c|}{ Total }} & Count & 211 & 56 & 9 & 32 & 308 \\
\hline & & $\begin{array}{l}\% \text { within Age of } \\
\text { respondents }\end{array}$ & $68.5 \%$ & $18.2 \%$ & $2.9 \%$ & $10.4 \%$ & $100.0 \%$ \\
\hline
\end{tabular}

Table 4: Chi-square test

\begin{tabular}{|c|c|c|c|}
\hline \multicolumn{4}{|c|}{ Chi-Square Tests } \\
\hline & Value & Df & Asymp. Sig. (2-sided) \\
\hline Pearson Chi-Square & $25.525^{\text {a }}$ & 12 & .013 \\
\hline Likelihood Ratio & 27.774 & 12 & .006 \\
\hline Linear-by Linear Association & .045 & 1 & .831 \\
\hline N of Valid Cases & 308 & & \\
\hline a. 10 cells (50.0\%) have expected count less than 5. The minimum expected count is .03. \\
\hline
\end{tabular}

From the above Pearson Chi- Square statistic table it can be seen that X2 $=25.525$ and $\mathrm{p}<0.05$, such data revealed that null hypothesis is rejected.

So it is concluded that there exists a significant relationship between gender of respondents and frequency of using social media.

\section{CONCLUSION}

This study concludes that the respondents whose age group is between 41 to 50 years having maximum experience i.e. around 15 years experience while respondents whose age is 60 or above are not having much experience about investment through social media platforms. This study also found that the respondents whose age between 41 to 50 year using social media apps frequently while respondents whose age is 60 or 


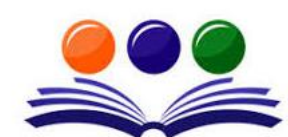

GRAND ACADEMIC PORTAL RESEARCH JOURNALS

\section{A GLOBAL JOURNAL OF SOCIAL SCIENCES \\ ( ISSN - 2581-5830 ) \\ Impact Factor: SJIF - 4.998, IIFS - 4.375}

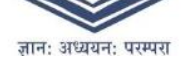

above are using social media apps occasionally. So finally we can conclude that more investments are done by respondents who are using social apps and aware about it.

\section{REFERENCES}

Power, D. J., \& Phillips-Wren, G. (2011). Impact of social media and Web 2.0 on decision-making. Journal of decision systems, 20(3), 249-261.

Bashir, T., Javed, A., Butt, A.A., Azam, N., Tanveer, A., Ansar, I., (2013). An Assessment Study on the "Factors Influencing the Individual Investor Decision Making Behavior." Journal of Business and Management. Vol. 7, Issue-5, Pg. 37-44.

Paniagua, J., \& Sapena, J. (2014). Business performance and social media: Love or hate? Business horizons, 57(6), 719-728.

Palanissamy, A. (2014). Investor-relations-integrating social media into board-Oman perspective. European Journal of Business and Management, 6(24), 108-113.

Jin, F., Wu, A., \& Hitt, L. (2017, January). Social Is the New Financial: How Startup Social Media Activity Influences Funding Outcomes. In Academy of Management Proceedings (Vol. 1, p. 13329). Academy of Management.

www.convinceand convert.com 